\title{
Fiebre y placas dolorosas en manos. ¿Cuál es el diagnóstico?
}

\section{Fever and Painful Plaques on Hands. What is your Diagnosis?}

Paciente de 70 años, que tras presentar posible infección respiratoria en días previos, acude por fiebre, artralgias y aparición de lesiones cutáneas. Presenta temperatura de 38,20 y en la piel se observan placas violáceas dolorosas que afectan a dorso de manos, además de placas eritematosas a nivel periorbitario.

La analítica mostró 7.300 leucocitos/ $\mu$ l (82\% neutrófilos) y glucemia de $237 \mathrm{mg} / \mathrm{dl}$, siendo el resto normal. La radiografía de tórax fue normal. Se realizó biopsia cutánea que mostró neutrófilos y edema importante en la dermis y ausencia de vasculitis, datos característicos de síndrome de Sweet.

El paciente recibió tratamiento con prednisona oral en pauta descendente, consiguiendo la remisión del cuadro en pocos días.

El Síndrome de Sweet o dermatosis neutrofílica febril aguda consiste en una inflamación de la piel en forma de placas eritematosas o violáceas, a veces con aspecto de pseudovesículas, y otras formación de pústulas, que suelen asentar en región facial, parte superior del tronco y manos, y se acompañan en muchos casos de fiebre, afectación articular y neutrofilia ${ }^{1}$, lo que obliga a realizar diagnóstico diferencial con un cuadro infeccioso u otros enfermedades neutrofílicas (pioderma gangrenoso...) o cutáneas varias (toxicodermias, eritema multiforme, paniculitis. . .). El diagnóstico clínico se apoya en criterios clínicos e histológicos (Tabla 1). Puede aparecer a cualquier edad, y en ocasiones asociar afectación sistémica (pulmón, SNC, intestino, hígado...).

Aunque casi un $70 \%$ son idiopáticos tiene diversos desencadenantes (Tabla 2): infecciones (por estreptococos, gérmenes que provocan afectación intestinal, etc), autoinmunes (enfermedad inflamatoria intestinal, Behçet. . .), paraneoplásicos (10-30\%², sobre todo tumores hematológicos, aunque también sólidos), embarazo o por toma de fármacos. Sería recomendable el despistaje de neoplasia cuando aparezca en pacientes mayores sin etiología clara, si existen lesiones atípicas, en casos recurrentes o cuando se asocia a alteraciones en el hemograma ${ }^{1,3}$. El tratamiento se puede realizar con corticoides, yoduro potásico o colchicina.

\section{Bibliografía}

1. Ginarte M, Toribio J. Sweet's syndrome. Med Clin (Barc). 2009; 133(1):31-5.

2. Wojcik AS, Nishimori FS, Santamaría JR. Sweet's syndrome: a study of 23 cases. An Bras Dermatol. 2011; 86(2):265-71.

3. Cohen PR, Kurzrock R. Sweet's syndrome and malignancy. Am J Med. 1987; 82(6):1220-6

\section{Diagnóstico}

Síndrome de Sweet

\section{Juan Manuel Barja López ${ }^{1}$, Cristina Prada González²}

${ }^{1}$ Servicio de Dermatología, ${ }^{2}$ Servicio de Medicina Interna. Hospital El Bierzo. Ponferrada. Sacyl. León

Como citar este artículo: Barja López JM, Prada González C

Sindrome de Sweet. Galicia Clin 2013; 74 (4): 196

Recibido: 23/4/2013; Aceptado: 1/8/2013
Figura 1. Placas dolorosas en dorso de las manos

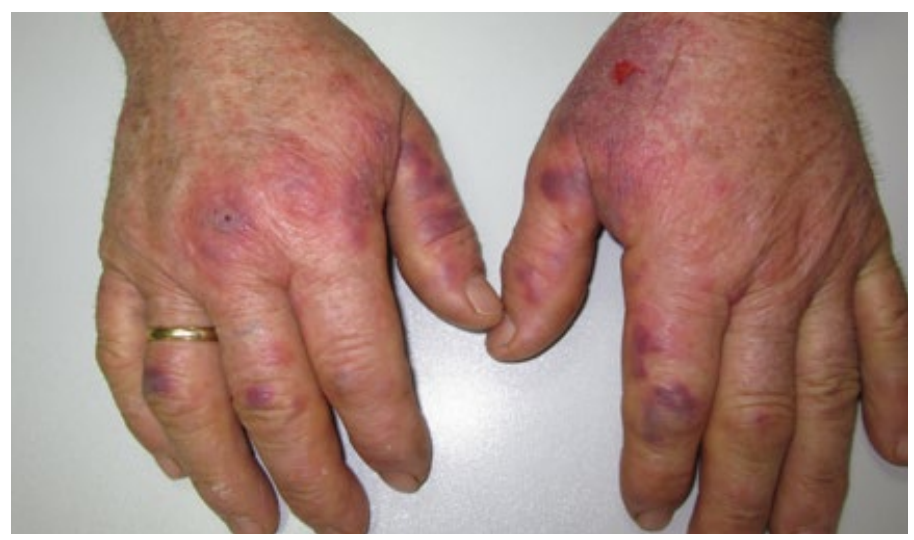

Figura 2. Placa eritematosa periorbitaria

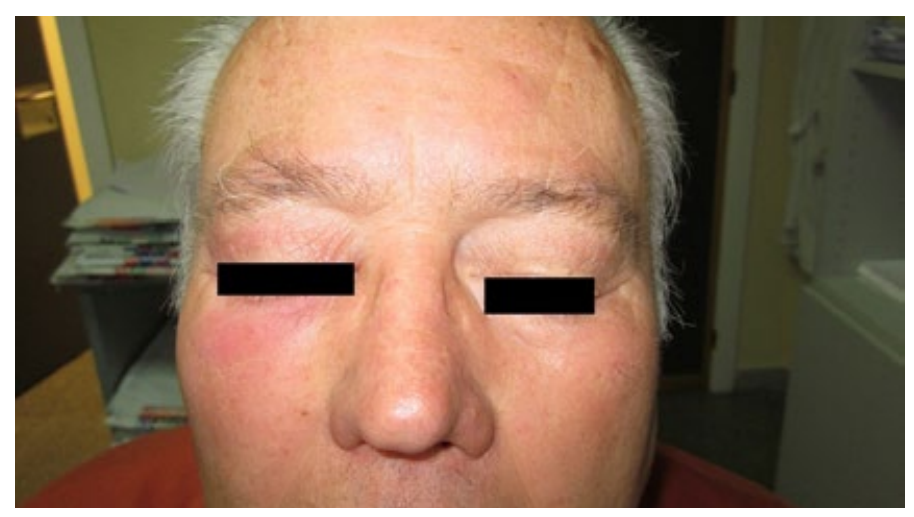

Tabla 1. Criterios diagnósticos de Síndrome de Sweet

\begin{tabular}{|c|c|}
\hline Criterios mayores & Criterios menores \\
\hline $\begin{array}{l}\text { Fiebre de comienzo abrupto } \\
\text { Histología con infiltrado } \\
\text { neutrofilico sin vasculitis }\end{array}$ & $\begin{array}{l}\text { Fiebre superior a } 38^{\circ} \\
\text { Asociación con causas relatadas en tabla } 2 \text {. } \\
\text { Excelente respuesta a corticoides o yoduro potásico. } \\
3 \text { de los siguientes } 4 \text { criterios de laboratorio: } \\
\text { Leucocitosis }>8000 \text {, neutrofila }>70 \%, \text { VSG }>20, \text { PCR alta }\end{array}$ \\
\hline Se necesita cumplir ambos & Se necesita cumplir por lo menos 2 de estos. \\
\hline
\end{tabular}

Tabla 2. Etiología del Síndrome de Sweet

\begin{tabular}{|l|l|}
\hline Idiopático & \\
\hline Infecciones & Estreptococo, Yersinia, Micobacterias, CMV, VIH \\
\hline Asociado a malignidad & $\begin{array}{l}\text { Neoplasias hematológicas, cáncer genitourinario, } \\
\text { mama, colon }\end{array}$ \\
\hline $\begin{array}{l}\text { Asociado a enfermedades } \\
\text { autoinmunes }\end{array}$ & $\begin{array}{l}\text { S. de Behçet, sarcoidosis, dermatomiositis, lupus, artritis } \\
\text { reumatoide, S. de Sjogren, enfermedad inflamatoria } \\
\text { intestinal }\end{array}$ \\
\hline Medicamentos & $\begin{array}{l}\text { Factor estimulante de colonias granulocítico, } \\
\text { furosemida, hidralacina, minociclina, cotrimoxazol, } \\
\text { anticonvulsionantes, anticonceptivos orales }\end{array}$ \\
\hline Embarazo & \\
\hline
\end{tabular}

